\title{
Simulating a convectional heat transfer in buildings with radiant gas heating
}

\author{
Anton N. Ermolaev ${ }^{1, *}$, Olga V. Khaustova ${ }^{2}$, and Ilya A. Turaev ${ }^{2}$ \\ ${ }^{1}$ Tyumen industrial University, 625000 Tyumen, Russia \\ ${ }^{2}$ National Research Tomsk Polytechnic University, 634050 Tomsk, Russia
}

\begin{abstract}
The paper presents the results of the simulation of convectional heat transfer in buildings with radiant gas heating. The study is provided by numerical researches based on existing buildings and numerical studies with the use of modern software ANSYS Multiphysics Fluent, Autodesk Inventor. The data reliability is ensured by the use of fundamental laws in regards to numerical researches and approved mathematic models application; certificated measuring equipment; licensed software products; matching of numerical and experimental researches; matching of the simulation with other works. The simulation of luminous infrared gas emitters of all thermal powers $(5,10,15,20,30,40 \mathrm{~kW})$ in pre-wall and central placements at heights of $4,5,6,7,8,9,10$ m was conducted. Gasfired infrared heat emitters with heat output of $5,10,15,20,30,40 \mathrm{~kW}$ were studied. Obtained function of IR-heated zone diameter is close to logarithmic function of thermal output. Effective emitter placement heights and least horizontal pitch for the given room volume were determined.
\end{abstract}

\section{Introduction}

It's essential to know the thermal performance $[1,2]$ when designing and operating a radiant gas heating that is the radiant heat flow during the operation of infrared gas emitters [3 -5$]$. The aim of the work is to identify the dependences, which describe the thermal rate and heat flow density distribution during the operation of infrared gas burners. Another aim is to determine the effective spots for emitters in terms of the room space.

Together with the fact that buildings with radiant gas heating have high thermal performance $[7,8]$, they also have a number of drawbacks $[9,10]$ : their upper zone is overheated; their walls are often covered by smut leading ultimately to subsequent destruction. To solve the problems assigned, several numerical, experimental and analytic researches were executed.

Problem solving is provided by numerical researches based on existing buildings and numerical studies with the use of modern software ANSYS Multiphysics Fluent [10 - 15], Autodesk Inventor.

The data reliability is ensured by the use of fundamental laws in regards to numerical researches and approved mathematic models application [3-5, $10-13]$; certificated

\footnotetext{
Corresponding author: ermolaevanton03@gmail.com
} 
measuring equipment; licensed software products; matching of numerical and experimental researches; matching of the simulation with other works.

There are several heat flow control methods: the infrared gas emitter design, its relative arrangement in the room, materials of all system elements, optic properties of environment. Consequently, there is a large number of variables in parametric model. We carried out a series of CFD-experiments to obtain temperature fields formed in a computational domain. Computational domain was convectional heat transfer in buildings with radiant gas heating system (Fig. 1).

\section{Method of the research}

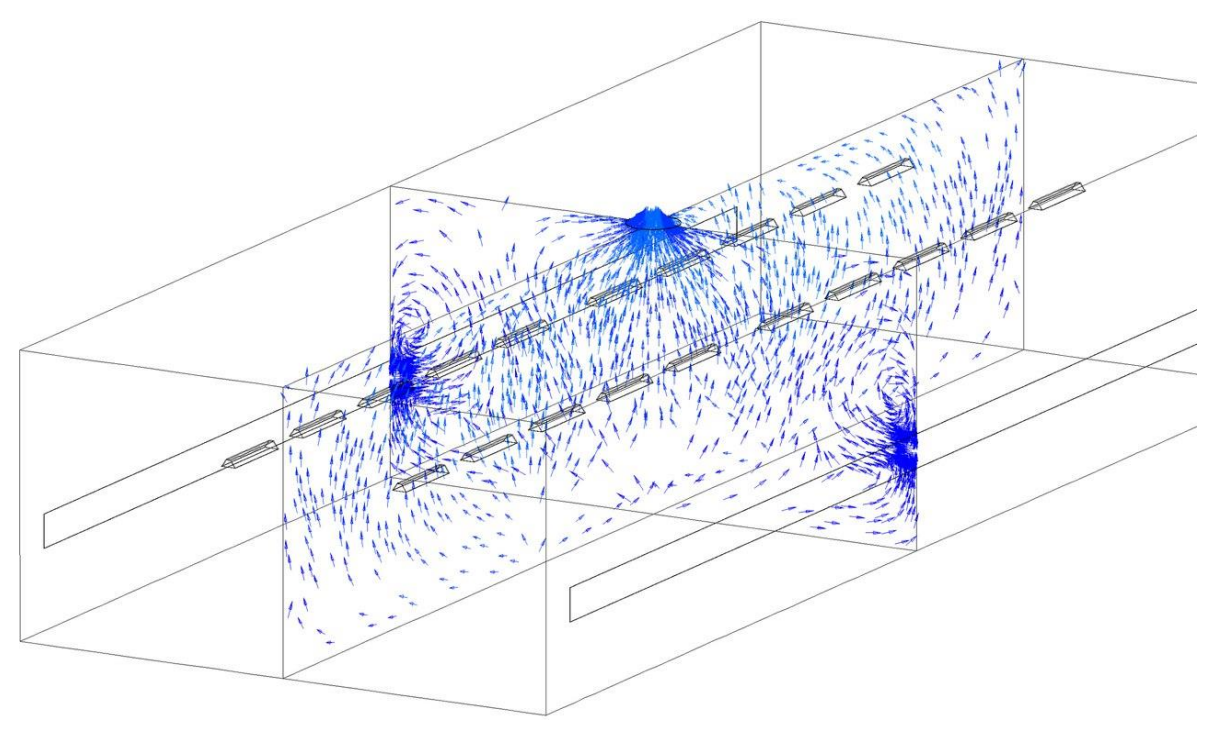

Fig. 1. Isometric view of computational domain.

The analysis of differentiated parameter evaluation possibility of microclimate was executed by simulation modeling of environment inside the modular prefabricated industrial building (workshop) with $60 \times 24 \times 12$ structure gauge and radiant gas heating. The most typical and practically significant sets of boundary conditions were considered. To identify the most effective way of managing the air and heat flows inside the industrial building, 125 most typical arrangements of radiant gas heating system were considered.

The simulation of luminous infrared gas emitters of all thermal powers $(5,10,15,20$, $30,40 \mathrm{~kW}$ ) in pre-wall and central placements at heights of 4, 5, 6, 7, 8, 9, $10 \mathrm{~m}$ was conducted [3 - 5]. Gas-fired infrared heat emitters with heat output of 5, 10, 15, 20, 30, 40 $\mathrm{kW}$ were studied. The gas pressure before the inlet nozzle was $1270 \mathrm{~Pa}$. The air-fuel ratio (AFR) was 9.996. All high-temperature gas-fired infrared emitter's tech specs are taken according to nominal data. Heat exchange with the environment is restricted by four external walls and light holes with the conditions arranged for the third type of heat transfer. Outside environment temperature of the coldest five days $-35{ }^{\circ} \mathrm{C}$ was taken. The wall material is sandwich-panel made of polyurethane $(\lambda=0.019 \mathrm{~W} / \mathrm{m} \cdot \mathrm{K}, \mathrm{C}=$ $1.47 \mathrm{~kJ} / \mathrm{kg} \cdot \mathrm{K})$. The glass-material with reduced thermal conductivity of $\lambda=1 \mathrm{~W} / \mathrm{m} \cdot \mathrm{K}$ and width of $0,27 \mathrm{~m}$ was set for the light holes as it matches the window thermal insulance of $0.42 \mathrm{~m}^{2} \cdot \mathrm{K} / \mathrm{W}$. Air exchange in the building is provided by general ventilation, which implies air induction in lower part of the building and air intake in the upper. Mass air flow determines by volume of the room and air change rate of 0.5 . 
All geometric model elements of calculated area (walls, light holes, vent holes, heating devices) were modeled in Ansys DesignModeller. There is a calculation subarea inside the area, which includes flame chamber and reflector. Heat exchange and emitter calculation area are plotted as conjugated gas-dynamic areas with doubled walls in the place of contact. Discretization was made uneven to obtain the acceptably accurate and efficient calculations. The grid is more accurate in the area of the highest gradient. Primary calculations with the use of grids with different topology and number of cells have shown that approved grid with $3 \cdot 10^{6}$ control volumes provides low results sensitivity to the further mesh grinding.

\section{Results and Conclusion}

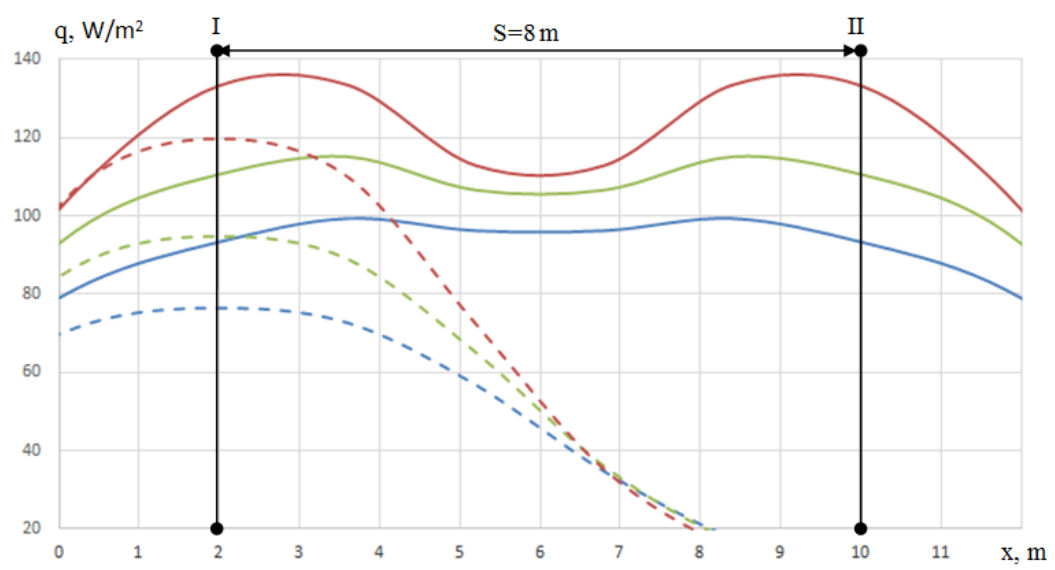

Fig. 2. Heat flow intensity in the working area at one-row(dotted line) and multi-row(continuous line) placements of emitters with the power of $20 \mathrm{~W}(--8 \mathrm{~m},-9 \mathrm{~m},-10 \mathrm{~m}) \mathrm{I}, \mathrm{II}-$ placements of first and second emitters; $\mathrm{S}$ - emitters placement pitch, $\mathrm{m}$.

To verify the heat comfort task fulfillment, thermal exposure intensity distribution of working area ( $1 \mathrm{~m}$ above the floor), depended on the parameters researched, was calculated. According to Russian set of rules, infrared radiation intensity of working area mustn't exceed $150 \mathrm{~W} / \mathrm{m}^{2}$. The infrared gas emitter placement heights of $4 \mathrm{~m}\left(5 \mathrm{~kW}, 119.3 \mathrm{~W} / \mathrm{m}^{2}\right)$; $6 \mathrm{~m}\left(10 \mathrm{~kW}, 106.1 \mathrm{~W} / \mathrm{m}^{2}\right) ; 7 \mathrm{~m}\left(15 \mathrm{~kW}, 116.9 \mathrm{~W} / \mathrm{m}^{2}\right) ; 8 \mathrm{~m}\left(20 \mathrm{~kW}, 119.3 \mathrm{~W} / \mathrm{m}^{2}\right) ; 10 \mathrm{~m}(30$ $\left.\mathrm{kW}, 114.6 \mathrm{~W} / \mathrm{m}^{2}\right) ; 10 \mathrm{~m}\left(40 \mathrm{~kW}, 148.2 \mathrm{~W} / \mathrm{m}^{2}\right)$ match this requirement. It was derived that the higher infrared gas emitters are placed, the more uniform local heat flow distribution and the lower amplitude in the IR-heated zone center are. IR-heated zone center implies the heating surface area onto which it didn't fall less than $10 \mathrm{~W} / \mathrm{m}^{2}$ from the infrared gas emitter researched. Obtained function of IR-heated zone diameter is close to logarithmic function of thermal output in the researched range of variables (Fig. 2). 


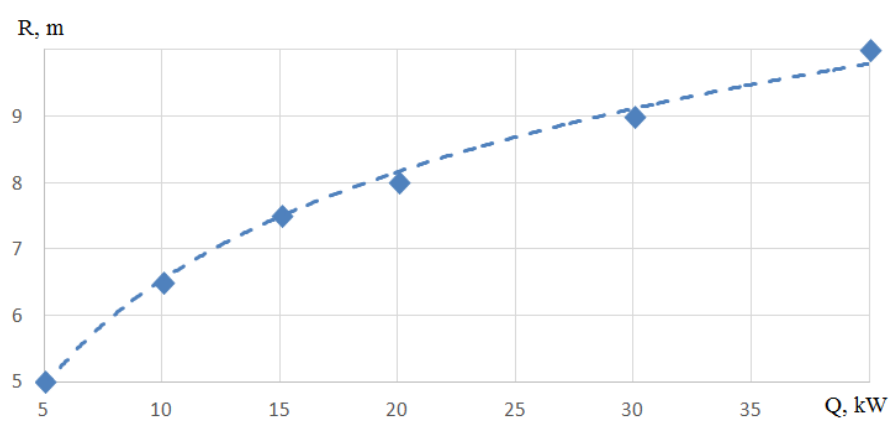

Fig. 3. Impact of gas-fired infrared emitter's thermal output on the radius of IR-heated zone.

Practically applicable dependences were derived. They can be used in gas heating system designing as they describe thermal rate and heat flow intensity distribution in the working area of the building. Effective emitter placement heights and least horizontal pitch for the given room volume were determined.

It was proved in the research that the most uniform working area radiation intensity can be obtained by setting high-temperature gas-fired infrared heat emitter of the same thermal output at a distance, shown in the Fig. 3.

\section{References}

1. Y. M. Luo, L. Chevalier, F. Utheza, Int. Polym. Process. 30, 554 (2015)

2. M. Ostafin, M. Balkenhol, J. Erlemeyer, M. Köhler. Mater. Werks. 41, 11 (2010)

3. A. N. Ermolaev, O. V. Khaustova, MATEC Web Conf. 141, 01019 (2017)

4. A. N. Ermolaev, S. A. Khaustov, MATEC Web Conf. 110, 01024 (2017)

5. A. N. Ermolaev, S. A. Khaustov, MATEC Web Conf. 110, 01038 (2017)

6. P. S. Gergelizhiu, S. A. Khaustov, R. B. Tabakaev, P. Y. Novoseltsev, A. V. Kazakov, A. S. Zavorin, Proc. of 2014 Int. Conf. on Mechanical Engineering, Automation and Control Systems (Tomsk, 2014)

7. D. Patino, B. Crespo, J. Porteiro, J. L. Miguez. Appl Therm Eng. 100, 849 (2016)

8. S. A. Khaustov, A. V. Kazakov, G. A. Cherkashina, L. A. Sobinova, EPJ Web Conf. 110, $01028(2016)$

9. K. A. Al-attab, J. C. Ho, Z. A. Zainal, Exp. Therm Fluid Sci. 62, 1-8 (2015)

10. S. A. Khaustov, A. S. Zavorin, K. V. Buvakov, and V. A. Sheikin, EPJ Web Conf. 82, 01039 (2015)

11. S. A. Khaustov, A. V. Kazakov, G. A. Cherkashina, L. A. Sobinova, EPJ Web Conf. 110, 01028 (2016)

12. J. A. Oraz, I. E. Korzilova, A. N. Ermolaev, S. A. Khaustov, A. Y. Dolgih, MATEC Web Conf. 92, 01001 (2016)

13. S. A. Khaustov, Y. A. Belousova, K. V. Buvakov, A. Y. Dolgih, R. N. Kulesh, IFOST 2016 Proceedings 2, 548 (2016)

14. S. A. Khaustov, A. S. Zavorin, K. V. Buvakov, N. A. Zakharushkin, MATEC Web Conf. 19, 01020 (2014)

15. S. A. Khaustov, A. S. Zavorin, K. V. Buvakov, L. D. Kudryashova, A. V. Tshelkunova, EPJ Web Conf. 82, 01041 (2015) 